\title{
Effect of extrusion on the rumen undegradable protein fraction of lupins
}

\author{
T.S. Brand ${ }^{1,2 \#} \&$ L. Jordaan ${ }^{2}$ \\ ${ }^{1}$ Directorate: Animal Sciences, Department of Agriculture, Western Cape Government, Private Bag X1, Elsenburg, 7607, \\ South Africa \\ ${ }^{2}$ Department of Animal Sciences, University of Stellenbosch, Private Bag X1, Matieland, 7602, South Africa
}

(Submitted 11 March 2020; Accepted 24 June 2020; Published 28 November 2020)

\author{
Copyright resides with the authors in terms of the Creative Commons Attribution 4.0 South African Licence. \\ See: http://creativecommons.org/licenses/by/4.0/za \\ Condition of use: The user may copy, distribute, transmit and adapt the work, but must recognise the authors and the South African \\ Journal of Animal Science.
}

\begin{abstract}
Lupins are highly degradable in the rumen, and do not provide enough bypass protein for highproducing ruminant animals. The effects of extrusion on dry matter (DM) and crude protein (CP) rumen degradability of Lupinus albus and Lupinus angustifolius were determined in situ. Samples of both types of lupin were extruded at maximum temperature, which reached $116{ }^{\circ} \mathrm{C}$. Six Dohne Merino wethers fitted with rumen cannulas were used in this trial. Samples were incubated in the rumen at intervals of $0,2,4,12,36$, and 48 hours. This procedure was repeated in two sheep per treatment and in three periods, giving a total of six observations for each variable. Extrusion lowered the soluble fraction of CP and increased the potential degradable fraction without affecting its rate of degradation. It also lowered the effective degradability of $\mathrm{CP}$ of both types of lupin by $28 \%$ at an outflow rate of $0.08 \%$ per hour. No differences were observed between types. Extrusion modified the ruminal degradation parameters and decreased effective rumen degradation, especially at faster outflow rates. Thus, the rumen undegradable protein (RUP) fraction of lupins was increased by extrusion and lupins could be used more efficiently in ruminant diets. This study showed that the benefits of extrusion could be reached at a relatively low temperature of $116^{\circ} \mathrm{C}$ to reduce the possibility of heat damage.
\end{abstract}

Keywords: bypass protein, crude protein, degradability, digestion, in sacco, in situ, ovine, protein source, ruminant, sheep

\#Corresponding author: tersb@elsenburg.com

\section{Introduction}

Plant protein sources make up the second largest proportion of livestock diets after energy sources, of which soybean oilcake meal is the most common (Tona, 2018). Soyabeans face market competition with human food demands, especially in developing countries (Mengesha, 2012). This feed-food competition has led to the necessity to explore the use of local cheaper alternative protein sources in livestock feed formulations (Tona, 2018).

Lupinus is a diverse genus with many species. However, only four are cultivated commercially, of which the two most commonly used are broad-leaf Lupinus albus and narrow-leaf Lupinus angustifolius (Abraham et al., 2019). Lupins are legumes that are cultivated in regions with Mediterranean climates, especially where monoculture has been practised in the past (Brand et al., 1992), and have been grown successfully in the Western Cape area of South Africa for many years. Lupins can be considered a local and inexpensive protein source compared with imported soybean meal. They are characterized by high grain productivity, are adapted to poor and barren low pH soils, have fewer nitrogen fertilizer requirements than other crops, are suggested to be cheaper than oilseed proteins, and are easy to store and handle because of their durable hull (Abraham et al., 2019). Although lupins have high CP values (35\%), they are highly rumen degradable (80\%) compared with soybean oilcake meal which has $40 \% \mathrm{CP}$ and is $78 \%$ rumen degradable protein (RDP) (INRA-CIRAD-AFZ, 2020). Therefore, they are currently not included in large quantities in ruminant diets (Brand et al., 1992; Boguhn et al., 2008). This means that for lupins to be used optimally as the main protein source in diets for highly productive ruminants they have to be treated to reduce rumen degradability (Dijkstra et al., 2005). 
Extrusion is a process in feed manufacturing in which heat and pressure are applied in the presence of moisture, most commonly for oil extraction, but more recently to decrease the rumen degradability of protein sources (White et al., 2007; Zagorakis et al., 2015). The physical characteristics of the feed are altered because extrusion promotes starch gelatinization and a partial Maillard reaction, which improves its durability (Chang \& Wang, 1999; Svihus et al., 2005; Solanas et al., 2008). Extrusion also causes denaturing of proteins, which decreases protein solubility and thus decreases the ruminal degradability of protein in feeds (Barchiesi-Ferrari \& Anrique, 2011). The RUP fraction is thus increased, providing greater quantities of amino acids for absorption (Solanas et al., 2008). Temperatures above $180{ }^{\circ} \mathrm{C}$ may result in irreversible effects of damaged proteins, but the process does not compromise protein degradability in the small intestine at temperatures below $180^{\circ} \mathrm{C}$ (Solanas et al., 2008). Besides temperature, the time that the feed is exposed to the heat and pressure and the amount of moisture contribute to the characteristics of the product. The optimal conditions for extrusion of lupins have not been established, but it offers the possibility of better utilization of a plant protein source (Van Barneveld, 1999). This may lead to lupins playing a larger role as a main protein source in ruminant feeds. Feed databases lack data on the effect of processing on protein sources, so data obtained by studies may aid in formulating feeds.

The aim of this study was to evaluate the effect of extrusion on DM and CP ruminal degradability of broad-leaf Lupinus albus and narrow-leaf Lupinus angustifolius.

\section{Materials and Methods}

Ethical clearance for this research was granted by the Animal Care and Use Research Ethics Committee of the University of Stellenbosch (Ethical clearance number \#0378 and \#0379). Six DohneMerino wethers with average live mass of approximately $80 \mathrm{~kg}$, and which had been fitted with rumen cannulas, were used in this trial. The sheep were housed in enclosed individual pens $(1 \mathrm{~m} \times 2 \mathrm{~m})$ at Welgevallen Experimental Farm of the University of Stellenbosch for the duration of the trial. The sheep had ad libitum access to clean water and were supplied a basal diet of wheat straw and lucerne hay (50: 50) ad libitum during the experimental period. The feed was replenished twice daily (every morning and evening) as necessary. Daily intake was estimated as $3 \%$ of bodyweight. The sheep had been adapted to the feed before the in-situ trial started.

Locally produced seeds of Lupinus albus (BL) and Lupinus angustifolius (NL) were sourced. Half were kept raw and the other half were extruded with an Insta Pro 2000RC extruder at a commercial feed mill, with temperatures reaching a maximum of $116^{\circ} \mathrm{C}$. The four types of lupin seed that were tested in this trial were L. albus not extruded (BL), L. albus extruded (BLE), L. angustifolius not extruded (NL) and L. angustifolius extruded (NLE). Samples were milled through a 1-mm screen with a Wiley mill (Thomas Scientific, Swedesboro, NJ, USA) for further analysis.

The DM and CP degradability of the lupins (control and extruded) were determined by the in situ technique (Ørskov \& McDonald, 1979). The seeds were dried in a force draught oven for a minimum of 48 hours at $60^{\circ} \mathrm{C}$, after which $5 \mathrm{~g}$ samples were weighed off on a digital scale and inserted in dried weighed and marked polyester bags $(10 \mathrm{~cm} \times 11 \mathrm{~cm})$ with an average pore size of $53 \mu \mathrm{m}$. The bags were tied with nylon strings of various lengths to prevent them from knotting in the rumen and to ensure easy retrieval. Bags were incubated in the rumen for various time intervals, namely $2,4,12,36$, and 48 hours, with an allout approach. An incubation series started when the first bag (representing the 48-hour interval) was inserted into the rumen cannula at $09 \mathrm{~h} 00$. Bags were added as the incubation period shortened. Incubation was ended when all of the bags were removed at the same time after 48 hours. After removal, the bags were submerged in ice water to stop further degradation rapidly and washed under running tap water until the water squeezed from them was clear. The 0 -hour bag was prepared in the same way and washed but was not placed in the rumen. All bags were dried after incubation in a force-draught oven for a minimum of 48 hours at $60{ }^{\circ} \mathrm{C}$. This procedure was repeated in two sheep per treatment in three periods as a completely randomized design, giving a total of six observations for each variable.

After the bags had been dried for 48 hours at $60^{\circ} \mathrm{C}$, the nylon strings were removed, and the dried bags were weighed to determine the DM residue. The nitrogen content (percentage $N$ ) of the residue was then determined with the Dumas combustion method (method 990.03) (AOAC, 2002) using a LECO TruMac $\mathrm{N}$ nitrogen determinator, version 1.3X (LECO Corporation, Michigan, USA). The CP content of the DM was determined by multiplying the percentage $\mathrm{N}$ by a factor of 6.25 .

Dry matter and CP disappearances were expressed as percentages of the amount that remained after rumen incubation. The percentage material degraded was fitted to the one-compartment model (Ørskov \& McDonald, 1979), by non-linear regression (SAS 9.4 software, 2014) to determine DM and CP degradability parameters:

Where: $D e g=$ degradation at time $T(\%)$;

$$
\operatorname{Deg}=A+B\left(1-\mathrm{e}^{-C T}\right)
$$


$A=$ rapidly soluble fraction; that is, it represents 0 hour disappearance (\%);

$B=$ the potential degradable fraction, which is asymptote (\%); and

$C=$ the rate of degradation of the $B$ fraction $(\% / h)$.

Ruminal retention time affects the extent of degradation and therefore a fractional outflow rate of undegraded protein from the rumen $(k)$ was taken into account when the percentage effective degradation $\left(\operatorname{Deg}_{\text {eff }}\right)$ was calculated as:

$$
\operatorname{Deg}_{\text {eff }}=A+\frac{B C}{C+k}
$$

at chosen $k$ values representing low, medium, and high levels of hourly intake: $\mathrm{k}=0.02, \mathrm{k}=0.04$ and $\mathrm{k}=$ 0.05 , and $\mathrm{k}=0.06$ and 0.08 , respectively. The parameter estimates for $A, B$ and $C$, and the values of $D e g_{\text {eff }}$ were analysed with a two-way analysis of variance including interaction using SAS 9.4 software (SAS Institute, Inc., Cary, North Carolina, USA). Differences among means were declared significant at $P \leq 0.05$ and tendencies were noted at $P<0.10$ using Bonferroni tests.

\section{Results and Discussion}

An interaction between the Lupin type and processing method was observed in the rapidly soluble fraction of DM. Lupinus albus that was not extruded was the highest $(58.7 \%)$, which differed significantly from the rest, namely NL (51.5\%), NLE (45.2\%) and BLE (44.6\%). No interaction effects were observed for the potentially degradable fraction of the $\mathrm{DM}$ and its rate of degradation. No significant difference was observed for the DM potential degradable fraction between lupin types, whereas extrusion increased the potential degradable fraction of the two types from $42.4 \%$ to $58.5 \%(P<0.001)$. No differences were found for the DM rate of degradation of the potential degradable fraction for lupin type or for the effect of extrusion. The in-situ DM disappearance parameters for the effect of extrusion on L. albus and L. angustifolius are summarized in Table 1.

Table 1 Effects of extrusion on parameter estimates characterizing in situ dry matter rumen disappearance of Lupinus albus and Lupinus angustifolius seeds

\begin{tabular}{llccc}
\hline & & \multicolumn{3}{c}{ Parameter estimates } \\
\cline { 3 - 5 } & & $A$ & $B$ & $C$ \\
\hline \multirow{4}{*}{ Lupin type } & L. albus & $51.7 \pm 1.3$ & $49.7 \pm 3.1$ & $0.099 \pm 0.02$ \\
& L. angustifolius & $48.3 \pm 0.9$ & $51.2 \pm 2.3$ & $0.076 \pm 0.02$ \\
& $P$-value & 0.051 & 0.691 & 0.412 \\
& Not extruded & $55.1^{1} \pm 0.9$ & $42.4^{2} \pm 2.4$ & $0.075^{2} \pm 0.02$ \\
& Extruded & $44.9^{2} \pm 1.2$ & $58.5^{1} \pm 3.0$ & $0.100^{1} \pm 0.02$ \\
& $P$-value & $<0.001$ & $<0.001$ & 0.382 \\
& L. albus not extruded & $58.7^{\mathrm{a}} \pm 1.3$ & $38.8^{\mathrm{b}} \pm 3.3$ & $0.078^{\mathrm{a}} \pm 0.02$ \\
& L. albus extruded & $44.6^{\mathrm{b}} \pm 2.1$ & $60.5^{\mathrm{a}} \pm 5.3$ & $0.120^{\mathrm{a}} \pm 0.04$ \\
& L. angustifolius not extruded & $51.5^{\mathrm{b}} \pm 1.3$ & $46.0^{\mathrm{ab}} \pm 3.3$ & $0.073^{\mathrm{a}} \pm 0.02$ \\
& L. angustifolius extruded & $45.2^{\mathrm{b}} \pm 1.2$ & $56.5^{\mathrm{a}} \pm 3.0$ & $0.080^{\mathrm{a}} \pm 0.02$ \\
& $P$-value & 0.026 & 0.168 & 0.535
\end{tabular}

$A$ : rapidly soluble fraction (\%), $B$ : fraction that will degrade over time (\%), C: rate of degradation of $B(\% / \mathrm{h})$

${ }_{\mathrm{a}, \mathrm{b}}$ Within a column and effect, means with a common superscript were not different, with probability $P=0.05$

No significant differences were observed in DM degradation over time between lupin types and processing methods at any outflow rate. The averages of effective degradation, irrespective of type and processing method) at outflow rates of $0.02,0.04,0.05,0.06$ and 0.08 per hour, were $86.9 \%, 80.1 \%, 77.7 \%$, $75.7 \%$, and $72.5 \%$, respectively. The $D e g_{\text {eff }}$ for all treatments at the various outflow rates can be seen in Table 2. 
Table 2 Effect of extrusion on in situ dry matter percentages of effective degradation of Lupinus albus and Lupinus angustifolius seeds

\begin{tabular}{|c|c|c|c|c|c|c|}
\hline & & \multicolumn{5}{|c|}{ Fractional outflow rate } \\
\hline & & $0.02 / \mathrm{h}$ & $0.04 / \mathrm{h}$ & $0.05 / \mathrm{h}$ & $0.06 / \mathrm{h}$ & $0.08 / \mathrm{h}$ \\
\hline & L. albus & $86.8 \pm 1.4$ & $80.4 \pm 2.1$ & $78.2 \pm 2.3$ & $76.4 \pm 2.5$ & $73.6 \pm 2.6$ \\
\hline \multirow[t]{3}{*}{ Lupin type } & L. angustifolius & $87.1 \pm 1.0$ & $79.8 \pm 1.5$ & $77.2 \pm 1.7$ & $75.0 \pm 1.8$ & $71.5 \pm 1.9$ \\
\hline & $P$-value & 0.892 & 0.813 & 0.714 & 0.637 & 0.523 \\
\hline & Not extruded & $88.4 \pm 1.0$ & $82.6 \pm 1.6$ & $80.4 \pm 1.8$ & $78.5 \pm 1.9$ & $75.5 \pm 2.0$ \\
\hline \multirow[t]{2}{*}{ Processing } & Extruded & $85.5 \pm 1.3$ & $77.7 \pm 2.1$ & $75.1 \pm 2.3$ & $72.9 \pm 2.4$ & $69.6 \pm 2.5$ \\
\hline & $P$-value & 0.104 & 0.085 & 0.087 & 0.089 & 0.088 \\
\hline
\end{tabular}

For in situ CP disappearance, significant interactions were observed for the soluble fraction and the potential degradable fraction, and main effects could not be interpreted. It is evident that extrusion lowered the CP soluble fraction $(P<0.05)$ in both types of lupin with $60.3 \%$ for Lupinus albus and $36.9 \%$ for the Lupinus angustifolius, respectively. The potential degradable fractions were increased by $32.3 \%$ for the Lupinus albus and $103.5 \%$ for the Lupinus angustifolius, respectively. No interaction or differences were observed between types of lupin or method of processing for the rate of degradation of the potential degradable crude protein fraction. The crude protein parameters are summarized in Table 3.

Table 3 Effects of extrusion on parameter estimates characterizing in situ crude protein rumen disappearance parameters of Lupinus albus and Lupinus angustifolius seeds

\begin{tabular}{llccc}
\hline & & \multicolumn{3}{c}{ Parameter estimates } \\
\cline { 3 - 5 } & & $A$ & $B$ & $C$ \\
\hline \multirow{3}{*}{ Lupin type } & L. albus & $56.5 \pm 1.1$ & $45.6 \pm 2.7$ & $0.153 \pm 0.1$ \\
& L. angustifolius & $55.8 \pm 0.8$ & $43.7 \pm 1.9$ & $0.246 \pm 0.1$ \\
& $P$-value & 0.616 & 0.576 & 0.352 \\
Processing & Not extruded & $74.7^{1} \pm 0.9$ & $23.1^{2} \pm 2.0$ & $0.260 \pm 0.1$ \\
& Extruded & $37.6^{2} \pm 1.1$ & $66.1^{1} \pm 2.6$ & $0.139 \pm 0.1$ \\
& P-value & $<0.001$ & $<0.001$ & 0.226 \\
Lupin type x processing & $80.9^{\mathrm{a}} \pm 1.2$ & $17.4^{\mathrm{b}} \pm 2.9$ & $0.177 \pm 0.1$ \\
& L. albus not extruded & $32.1^{\mathrm{d}} \pm 1.9$ & $73.7^{\mathrm{a}} \pm 4.5$ & $0.129 \pm 0.1$ \\
& L. albus extruded & $68.4^{\mathrm{b}} \pm 1.2$ & $28.9^{\mathrm{b}} \pm 2.9$ & $0.344 \pm 0.1$ \\
& L. angustifolius not extruded & $43.1^{\mathrm{c}} \pm 1.1$ & $58.8^{\mathrm{a}} \pm 2.6$ & $0.148 \pm 0.1$ \\
& L. angustifolius extruded & $<0.001$ & 0.001 & 0.453 \\
& $P$-value & & & \\
\hline
\end{tabular}

$A$ : rapidly soluble fraction (\%), $B$ : fraction that will degrade over time (\%), C: rate of degradation of $B(\% / \mathrm{h})$

${ }^{\mathrm{a}, \mathrm{b}}$ With a column and effect, means with a common superscript were not different with probability $P=0.05$

No marked differences were observed between lupin types at any outflow rate. However, extrusion lowered the effective degradability of crude protein significantly at every outflow rate (between $9.5 \%$ and $28.0 \%)$. Extrusion had the most pronounced effect at the highest outflow rate $(0.08 / \mathrm{h})$ where the reduction in CP effective degradability was $28.0 \%$. The CP effective degradability at various rates of passage from the rumen is presented in Table 4. 
Table 4 Effect of extrusion on in situ crude protein percentages of effective degradation of Lupinus albus and Lupinus angustifolius seeds

\begin{tabular}{|c|c|c|c|c|c|c|}
\hline & & \multicolumn{5}{|c|}{ Fractional outflow rate } \\
\hline & & $0.02 / \mathrm{h}$ & $0.04 / \mathrm{h}$ & $0.05 / \mathrm{h}$ & $0.06 / \mathrm{h}$ & $0.08 / \mathrm{h}$ \\
\hline & L. albus & $90.7 \pm 1.6$ & $82.7 \pm 2.2$ & $80.4 \pm 2.4$ & $78.6 \pm 2.6$ & $76.0 \pm 2.9$ \\
\hline \multirow[t]{3}{*}{ Lupin type } & L. angustifolius & $91.6 \pm 1.3$ & $86.9 \pm 1.8$ & $85.1 \pm 2.0$ & $83.6 \pm 2.2$ & $81.1 \pm 2.4$ \\
\hline & $P$-value & 0.677 & 0.157 & 0.159 & 0.170 & 0.194 \\
\hline & Not extruded & $95.7^{\mathrm{a}} \pm 1.4$ & $94.0^{\mathrm{a}} \pm 1.9$ & $93.2^{a} \pm 2.1$ & $92.6^{\mathrm{a}} \pm 2.3$ & $91.4^{a} \pm 2.5$ \\
\hline \multirow[t]{2}{*}{ Processing } & Extruded & $86.6^{b} \pm 1.6$ & $75.6^{b} \pm 2.1$ & $72.2^{b} \pm 2.4$ & $69.7^{b} \pm 2.5$ & $65.8^{\mathrm{b}} \pm 2.8$ \\
\hline & $P$-value & $<0.001$ & $<0.001$ & $<0.001$ & $<0.001$ & $<0.001$ \\
\hline
\end{tabular}

${ }^{a, b}$ Within a column and effect, means with a common superscript were not different with probability $P=0.05$

Extrusion appeared to lower the DM soluble fraction and to increase the potential degradable fraction with no differences in the rate of degradation of the potential degradable protein fraction. This conforms with the results of Barchiesi-Ferrari and Anrique (2011). Griffiths (2004) extruded lupins at $115-120{ }^{\circ} \mathrm{C}$ and found the DM soluble fraction was increased, which was unexpected. Aufrère et al. (2001) found extrusion increased the DM potential degradable fraction of lupins to about twice that of the unextruded control, whereas Griffiths (2004) did not find a significant difference in the potential degradable fraction. Griffiths (2004) found no difference in DM effective degradability of the potential degradable fraction at $0.08 / \mathrm{h}$ outflow rate by in 2004, which is in line with the findings of the current study. This means that extrusion did not have an effect on effective degradability of DM at any outflow rate, despite the effect on the degradability parameters.

Extrusion had a marked effect on the CP soluble fraction, lowering it from $74.7 \%$ to $37.6 \%$. This decreased solubility correlates with the findings of other authors. For example, Barchiesi-Ferrari \& Anrique (2011) and Barchiesi et al. (2018), who extruded dehulled L. albus at $120^{\circ} \mathrm{C}$ and $130{ }^{\circ} \mathrm{C}$ at $20 \%$ moisture, respectively, and found decreases of $12 \%$ (42.7\% to $37.4 \%)$ and $29 \%$ (34.2\% to $24.4 \%)$, respectively, in the $\mathrm{CP}$ soluble fraction. It seems that non-structural carbohydrates are prone to react with protein in the presence of heat and moisture, diminishing protein solubility at ruminal level (Solanas et al., 2008). Increases in the potential degradable fraction correspond to a reduced soluble fraction of feed (Barchiesi et al., 2018).

Extrusion increased the potential degradable CP fraction in the current study from $23.1 \%$ to $66.1 \%$. Barchiesi-Ferrari and Anrique (2011) found an increase in the CP potential degradable fraction of lupins because of extrusion, but this increase was not biologically significant. Solanas et al. (2008) and Barchiesi et al. (2018) did not find significant differences, possibly because they used dehulled lupins. Lampart-Szczapa et al. (2006) showed lower increases when they used dehulled lupins as they had lower moisture absorbance capacity, which probably affected the Maillard reaction negatively.

No differences were found in the rate of degradability of the potential degradable CP fraction in this study (average 0.2\%). Barchiesi-Ferrari and Anrique (2011) did not find significant differences for the rate of degradability of the potential degradable CP fraction (0.09\%). Solanas et al. (2008) found that extrusion lowered the rate of degradability of the potential degradable CP fraction from $0.248 \%$ to $0.124 \%$.

The effect of extrusion on CP effective degradability of lupins was clearly visible in this study. The greatest decrease of $28 \%$ in CP degradation was seen at outflow rate of $0.08 / \mathrm{h}(91.4 \%$ non-extruded to $65.8 \%$ extruded). This outflow rate corresponds to $8 \%$ per hour and represents an incubation time in the rumen of roughly 12.5 hours, which is generally used as an average value for high-producing cows. In this study, extrusion decreased CP effective degradability significantly at outflow rates $0.02 / \mathrm{h}(9.5 \%), 0.04 / \mathrm{h}$ (19.6\%), 0.05/h (22.5\%), 0.06/h (24.7\%), and 0.08/h (28.0\%). Barchiesi-Ferrari and Anrique (2011) found extrusion of lupins lowered CP effective degradability at these outflow rates: $0.02 / \mathrm{h}(2.1 \%), 0.05 / \mathrm{h}(2.4 \%)$, and $0.08 / \mathrm{h}(2.8 \%)$. These values might not be biologically significant. Solanas et al. (2008) showed extrusion decreased CP effective degradability at an outflow rate of $0.06 / \mathrm{h}$ from $84.9 \%$ to $77.4 \%$. Crude protein effective degradability in the current study was similar to the findings of Cros et al. (1992) and Aufrère et al. (2001), which resulted in an RUP increase of $8.96 \%$, allowing increasing metabolizable protein availability and consequently amino acid availability in the small intestine. Studies by Barchiesi et al. (2018) found decreased crude protein effective degradability at an outflow rate of $0.06 / \mathrm{h}$ of lupins through extrusion from 
$82.3 \%$ to $72.7 \%$, with an increased true ileal CP digestibility. It is well established that effective protein degradability is negatively related to nitrogen digestibility (Zagorakis et al., 2015). This confirms that high protein degradability (high soluble fraction) affects total tract protein digestibility negatively.

Different results among studies may be from processing conditions, the types and composition of feed sample preparation and the legume species. Most studies were done on $L$. albus and information about $L$. angustifolius is scarce.

Although there were no differences in degradation rates between the lupin types in the current study, it is important to look at other nutrients in these sources before using them to formulate feed diets. There are variations in degradability in feeds, and care must be taken when using degradability figures from the literature as some overlap should be expected (Erasmus et al., 1988).

This study showed that the benefits of extrusion could be reached at a relatively lower temperature $\left(116^{\circ} \mathrm{C}\right)$ than was previously advised $\left(130^{\circ} \mathrm{C}\right)$ (Solanas et al., 2008). Further improvement is still possible by adjusting the processing conditions. According to the literature, the effects of processing can be strengthened by increasing moisture and adding a source of reducing sugar (Hoskin \& Dimick, 1995; Solanas et al., 2005). A high carbohydrate content could favour development of the Maillard reaction and hence the possible encouraging effect of extrusion.

\section{Conclusion}

Extrusion modified the ruminal degradation parameters of $L$. albus and $L$. angustifolius, and decreased the effective rumen degradation of both types. Thus, the RUP fraction of lupins was increased with a reduction in CP rumen degradability of up to $28 \%$ at a high outflow rate. The effect of extrusion on protein degradability seemed to be more pronounced at a faster outflow rate. This means that the use of lupins, which had been limited in diets for high-producing animals because of their high RDP content, could be included at higher levels after extrusion. The extruded products should also be evaluated in terms of amino acid availability in the small intestine. This should be done through bioassays to generate the true ileal digestibility values of $\mathrm{CP}$ to be used in feeds. Further studies of extrusion conditions to determine the optimum temperature and moisture of lupins during processing are needed to optimize the RUP fraction of lupin cultivars. Further studies are also needed to determine the effect of feeding extruded lupins on the digestion and production performance of ruminants.

\section{Acknowledgements}

Acknowledgements are hereby made to the Western Cape Department of Agriculture for providing facilities for the study and for joint funding. In addition, Western Cape Agricultural Research Trust is thanked for joint funding of the study. Ms Laetitia Brundyn is acknowledged for her technical work on this study.

\section{Authors' contributions}

Concept and design: TSB; source of funding: TSB; data collection and analysis: TSB \& LJ; drafting of initial paper: $\mathrm{LJ}$; critical revision and final approval of version to be published: TSB. All authors substantial contributions to conception and design, acquisition of data, and analysis and interpretation of data. All the authors have seen and approved the manuscript being submitted.

\section{Conflict of Interest Declaration}

The authors certify that they have no affiliations with or involvement in any organization or entity with financial or non-financial interests in the subject matter and materials discussed in this manuscript.

\section{References}

Abraham, E.M., Ganopoulos, I., Madesis, P., Mavromatis, A., Mylona, P., Nianiou-Obeidat, I., Parissi, Z., Polidoros, A., Tani, E. \& Vlachostergios, D., 2019. The use of lupin as a source of protein in animal feeding: Genomic tools and breeding approaches. Int. J. Mol. Sci. 20, 851. DOI 10.3390/ijms20040851

AOAC, 2002. Official methods of analysis (17th ed.). Association of Official Analytical Chemists, Inc., Arlington, Virginia, USA

Aufrère, J., Graviou, D., Melcion, J.P. \& Demarquilly, C., 2001. Degradation in the rumen of lupin (Lupinus albus L.) and pea (Pisum sativum L.) seed proteins: Effect of heat treatment. Anim. Feed Sci. Tech. 92, 215-236. DOI 10.1016/S0377-8401(01)00262-0

Barchiesi, C., Williams, P. \& Velàsquez, A., 2018. Lupin and pea extrusion decreases the ruminal degradability and improves the true ileal digestibility of crude protein. Cien. Inv. Agr. 45, 231-239. DOI 10.7764/rcia.v45i3.1762

Barchiesi-Ferrari, C. \& Anrique, R., 2011. Ruminal degradability of dry matter and crude protein from moist dehulled lupin and extruded rapeseed meal. Chil. J. Agr. Res. 71, 430-436. DOI 10.4067/S0718-58392011000300014

Boguhn, J., Kluth, H., Bulang, M., Engelhard, T., Spilke, J. \& Rodehutscord, M., 2008. Effects of using thermally treated lupins instead of soybean meal and rapeseed meal in total mixed rations on in vitro microbial yield and performance of dairy cows. J. Anim. Physiol An. N. 92, 694-704. DOI 10.1111/j.1439-0396.2007.00767.x 
Brand, T.S., Franck, F., Brand, A.A., Durand, A. \& Coetzee, J., 1992. An evaluation of faba bean (Vicia faba) and lupin (Lupinus albus) stubble and seed for sheep. S.Afr. J. Anim. Sci. 22, 170-173.

Chang, Y.K. \& Wang, S.S., 1999. Advances in extrusion technology: Aquaculture/animal feeds and foods. Proceedings of the International Symposium on Animal and Aquaculture Feedstuffs by Extrusion Technology and the International Seminar on Advanced Extrusion Technology in Food Applications, 9-14 March 1998, Áquas de Lindóia, São Paulo, Brazil. Technomic Publishing Company, Lancaster, PA. ISBN 1566767172

Cros, P., Moncoulon, R., Bayourthe, C. \& Vernay, M., 1992. Effect of extrusion on ruminal and intestinal disappearance of amino acids in white lupin seeds. Can. J. Anim. Sci., 72, 89-96. DOI 10.4141/cjas92-010

Dijkstra, J., Forbes, J.M. \& France, J. (ed.), 2005. Quantitative aspects of ruminant digestion and metabolism. 2nd ed. CAB International, Wallingford, UK. ISBN 0851998143

Erasmus, L.J., Prinsloo, J. \& Meissner, H.H., 1988. The establishment of a protein degradability data base for dairy cattle using the nylon bag technique. 1. Protein sources. S. Afr. J. Anim. Sci. 18, 23-29.

Griffiths, J., 2004. The effect of extrusion on the degradability parameters of various vegetable protein sources. MSc Agric thesis, Department Animal Science, Stellenbosch University, South Africa.

Hoskin J.C. \& Dimick P.S., 1995. Non-enzymatic browning of foods. In: S. T. Beckett, Physico-chemical aspects of food processing. Springer, Boston, MA. Pp. 65-79.

INRA-CIRAD-AFZ Feed tables, 2020. Feed tables of composition and nutritional values of feed materials. https://www.feedtables.com/ Accessed 03 March 2020.

Lampart-Szczapa, E., Konieczny, P., Nogala-Kałucka, M., Walczak, S., Kossowska, I. \& Malinowska, M., 2006. Some functional properties of lupin proteins modified by lactic fermentation and extrusion. Food Chem. 96, 290-296. DOI 10.1016/j.foodchem.2005.02.031

Mengesha, M., 2012. The issue of feed-food competition and chicken production for the demands of foods of animal origin. Asian J. Poultry Sci. 6, 31-43. DOI 10.3923/ajpsaj.2012.31.43

Ørskov, E.R. \& McDonald, I., 1979. The estimation of protein degradability in the rumen from incubation measurements weighted according to rate of passage. J. Agr. Sci. Cambridge. 92, 499-503. DOI 10.1017/s0021859600063048

Solanas, E., Castrillo, C., Balcells, J. \& Guada, J. A., 2005. In situ ruminal degradability and intestinal digestion of raw and extruded legume seeds and soya bean meal protein. J. Anim. Physiol. An. N., 89, 166-171. DOI 10.1111/j.1439-0396.2005.00555.x

Solanas, E. M., Castrillo, C., Jover, M. \& de Vega, A., 2008. Effect of extrusion on in situ ruminal protein degradability and in vitro digestibility of undegraded protein from different feedstuffs. J. Sci. Food Agric. 88, 2589-2597. DOI $10.1002 /$ jsfa.3345

Svihus, B., Uhlen, A.K. \& Harstad, O., 2005. Effect of starch granule structure, associated components and processing on nutritive value of cereal starch: A review. Anim. Feed Sci. and Tech. 122, 303-320. DOI 10.1016/j.anifeedsci.2005.02.025

Tona, G.O., 2018. Current and future improvements in livestock nutrition and feed resources. Animal Husbandry and Nutrition. Pp. 147-169. DOI 10.5772/intechopen.73088

Van Barneveld, R.J., 1999. Understanding the nutritional chemistry of lupin (Lupinus spp.) seed to improve livestock production efficiency. Nutr. Res. Rev. 12, 203-30. DOI 10.1079/095442299108728938

White, C.L., Staines, V.E. \& Staines, M.v H., 2007. A review of the nutritional value of lupins for dairy cows. Aust. J. Agric. Res. 58, 185-202. DOI 10.1071/ar06109

Zagorakis, K., Liamadis, D., Milis, C., Dotas, V. \& Dotas, D., 2015. Nutrient digestibility and in situ degradability of alternatives to soybean meal protein sources for sheep. Small Ruminant Res. 124, 38-44. DOI 10.1016/j.smallrumres.2015.01.002 